\title{
Г.Г. Супрыгина
}

\section{ТРАНСФОРМАЦИЯ МИФА О ЛАНГЕМАРКЕ В НЕМЕЦКОЙ ИСТОРИИ ХХ В.}

\begin{abstract}
Статья посвящена созданию в начальный период Первой мировой войны военной пропагандой Германии мифа о Лангемарке. Его героями стали «молодые бойцы», погибшие в бою во Фландрии из-за бездарного руководства. Милитаристы превозносили героизм и самопожертвование павших, превращая их в код фронтового поведения, и навязывали его немецкой молодежи. Миф о Лангемарке использовался националистами Германской империи, Веймарской республики и Третьего рейха. В ФРГ этот миф утратил свой статус, его мемориалы рассматриваются ныне как «места памяти».

Ключевые слова: миф о Лангемарке; молодые бойцы Германии в Первой мировой войне; миф о Лангемарке в эпоху национал-социализма; Лангемарк как место памяти.
\end{abstract}

Многие немецкие авторы, изучавшие общественное настроение в Германии в самом начале Первой мировой войны, констатировали взрыв ура-патриотических националистических чувств у значительной части немцев, которые порой доходили до эйфории. Этот феномен получил в немецкой научной литературе название «августовское переживание». Исследователи указывают, что подобные настроения были присущи преимущественно слоям «образованной буржуазии», проживающей в урбанизированных центрах. Наиболее высокий уровень воодушевления был отмечен в ее молодежных группах. Эти чувства питали так называемые идеи 1914 г., которые еще до войны были сформулированы представителями интеллигенции рейха и оказали сильное воздействие на немецкое общество. Авторы «идей 1914 г.» категорически отвергали утверждения противников Германии о том, что ее целью в войне является борьба за расширение влияния в Европе и в мире. Они подчеркивали «непоколебимое миролюбие кайзера» и доказывали, что Германии «навязана война за само ее существование», поэтому она вынуждена обороняться [1]. Особую активность проявили профессора Берлинского университета, которые доказывали, что критикуемый противниками «немецкий милитаризм» играет позитивную роль в этой войне, так как защищает не только немецкую, но и западную культуру и цивилизацию от угроз с Востока и Запада. В начальный период войны под воздействием «идей 1914 г.» многие охваченные энтузиазмом немцы, особенно молодые, отправлялись на призывные пункты добровольцами, чтобы защитить «фатерланд», добиться для немцев «экономической свободы», достойного «места под солнцем».

В ходе военных действий, особенно после первых болезненных поражений, атмосфера воодушевления постепенно развеивалась, уступая место отрезвлению. Но осенью 1914 г. произошли события, которые были использованы официальной пропагандой для создания «мифа о Лангемарке», который помогал германским властям поддерживать моральный дух солдат. Немецкие вооруженные силы в первые недели войны в боях на территории Бельгии и в Пограничной битве с Францией добились ряда побед, имели стратегическое превосходство, но постепенно утрачивали его. Лишь в конце августа - со значительным отставанием от сроков, установленных планом молниеносной войны (блицкриг) Шлиффена, они пересекли границу Франции. После неудачного для германцев сражения на p. Марне 6-12 сентября они были вынуждены все чаще переходить к обороне. В следующей операции «Бег к морю» 16 сентября - 15 октября 1914 г. противники предпринимали отчаянные попытки обойти и охватить друг друга с открытых флангов, чтобы установить контроль над побережьем Северного моря и занять выгодные позиции для дальнейших наступлений. Но ни одна из сторон не достигла этой цели. В итоге операции линия обороны удлинилась до 180 км и концы «уперлись» в пролив Па-де-Кале.

В октябре ход битвы показал, что военные действия на Западном фронте все более утрачивают способность к маневренности и принимают позиционный характер. В такой ситуации германское Верховное военное командование было крайне заинтересовано в наступлении, которое могло бы поддержать боевой дух солдат, настроенных на блицкриг. Перед ним стояла также трудная задача, несмотря на огромные потери, довести численность вооруженных сил Германии до 5 млн человек, в том числе за счет обеспечения массового притока добровольцев. Для привлечения новобранцев в печати сообщалось, что на фронт добровольно уже отправились 1 млн мужчин. На самом деле число добровольцев не превышало 180 тыс. [2. S. 34]. Официальная пропаганда превозносила добровольцев как героев нации и призывала к подобному «доблестному поведению» тех, кто еще не явился на призывные пункты.

Призывы имели успех: хотя среди добровольцев были мужчины разных возрастов, но основную их массу составляли молодые люди. Это были студенты и даже гимназисты, служащие, рабочие, ремесленники, члены различных молодежных союзов. Многие юные новобранцы добивались приема на военную службу, прибегая к протекции влиятельных родственников, 
знакомых, реже благодаря собственной настойчивости. Известны случаи, когда военнослужащими становились подростки моложе 15 лет [2. S. 22]. Таким немецкая пресса уделяла особое внимание, называя их детьми-солдатами (Kindersoldaten). Информация о них была хорошим агитационным материалом, побуждала следовать их примеру. Несовершеннолетние солдаты должны были до достижения призывного возраста служить в обозах, в прифронтовых районах, в тыловых подразделениях. Но в кризисных ситуациях их отправляли в резервные полки и после краткосрочной подготовки бросали в бой [3].

После операции «Бег к морю» германское командование не утратило веру в возможность решительного удара. Оно поставило новую цель - захватить побережье Па-де-Кале для угрозы Великобритании. Германским командованием был разработан новый план наступления в Западной Фландрии, где на северо-западном участке фронта еще сохранялась возможность маневра (этой операции, получившей название первой фламандской битвы (всего состоялось четыре) придавалось особое значение). 14 октября в Гент прибыл даже Вильгельм II. Он обратился к солдатам с воззванием, в котором выражал уверенность в достижении этой важной стратегической цели [4]. Предполагалось, что победа в этой операции окажет позитивное воздействие на солдат всего Западного фронта. Основной целью немцев был захват французских портов на берегу Па-де-Кале (прежде всего Дюнкерка и Кале), через которые Британский экспедиционный корпус получал снабжение и пополнение из метрополии. Для главного удара по приказу военного министра Германии в октябре в помощь 4-й армии наспех было сформировано четыре корпуса, состоящих преимущественно из молодых добровольцев, ополченцев и резервистов зрелого возраста. Британцы тоже готовились к наступлению во Фландрии, чтобы осуществить с ее территории широкий охват германских армий во Франции и разбить их. Первая фламандская битва носила крайне ожесточенной характер, поскольку от ее исхода зависело решение вопроса о краткосрочной войне, на которую надеялись обе стороны.

Наступление германских войск против бельгийскофранцузских сил начались на вспомогательном направлении у р. Изер. 23 октября немцы сломили оборону изможденного противника и закрепились на правом берегу. Отступившие бельгийцы прибегли к радикальной мере: с 26 по 29 октября они открывали шлюзы и затапливали морскими водами долину Изера, превращая ее в непроходимое болото. Наводнение стало непреодолимой преградой для немцев, и победа осталась за союзниками [Ibid.]. Активные военные действия на Изере были прекращены, и противники перебросили свои основные силы в район Ипра, который стратегически являлся бастионом Дюнкерка и других портов Ла-Манша [5].

В ходе кровопролитных боев 20-21 октября англофранцузские войска создали вокруг Ипра дугообразный выступ протяжением в 20 км. Концентрическое наступле- ние немцев в направлении дуги продолжалось до середины ноября. Части 4-й и 6-й германских армий смогли продвинуться к Ипру, но решительного успеха не добились и здесь из-за прочной обороны британских армий, которым помогали французы. Постепенно из-за больших потерь напор немцев ослабел, и в конце октября их наступление остановилось. Германское командование решило все же добиться перевеса и к 10 ноября сосредоточило северо-западнее Ипра все имеющиеся резервы, чтобы сделать еще одну попытку сломить оборону союзников и нанести им решительное поражение. Но наступление провалилось, немцы добились лишь локальных успехов, так как англичане подтянули свежие резервы [6].

В этом последнем наступлении маневренной войны между Лангемарком и Биксхоте произошли события, интерпретация которых и стала основой «мифа о Лангемарке». В качестве ударной группы были спешно переброшены наспех обученные и слабо вооруженные солдаты 6-й резервной дивизии XXII корпуса, в составе которого было больше обычного студентов и даже гимназистов, «полных безрассудного энтузиазма 1914 года» [5]. Современные немецкие авторы ход событий излагают следующим образом: прибывшие в октябре на место неопытные рекруты 10 ноября 1914 г. получили приказ рано утром 11 ноября штурмовать передовые позиции англичан, которые представляли собой гряду холмов. На них расположились опытные стрелки, в том числе гвардейцы, вооруженные пулеметами и поддерживаемые артиллерией. С этих холмов они буквально скосили пулями и снарядами более 2 тыс. немецких резервистов, которые, согласно приказу, волнами беспомощно штурмовали высоты противника.

В работе Е. Буллита и Х. Буллита содержится письмо участника Ипрской битвы 17-летнего солдата А. Вильмера от 28 октября 1914 г., которое передает ужас, пережитый юношей в бою. Он сообщает, что хотел первоначально написать о большом наступлении во Фландрии, как это обещали его офицеры. «Но перед глазами стоят только немногие ужасные детали, которые я хотел бы как можно скорее забыть: сослуживец с кровоточащей культей, размозженное пулей лицо одного из моих товарищей» [7. S. 47, 49]. После битвы под Лангемарком 11 ноября Вильмар писал уже из лазарета: «...мы все знали, что началось решающее наступление. Все резервисты - к ним еще присоединилось много гимназистов и даже производственных учеников - находились близь Ипра. Наш командир сказал перед сражением, что большой прорыв будет совершать молодежь. И поэтому мы выступили в утреннем тумане, надеясь все время, что враг нас не заметит и мы сможем захватить его врасплох. Но все случилось по-другому: тишину разорвали раскаты грома и вспышки огня. Хуже не могло быть даже в аду. Воздух вскипал, настолько сильным был огонь пехоты и пулеметов. Вокруг меня раздавались крики и стоны, тщетные зовы санитаров...». Следующее послание с фронта его мать получила через пять дней от штабного врача. 
Он сообщал ей, что ее сын умер от последствий ранения пулей в легкое, которое он получил в битве под Лангемарком. Далее следовали типичные слова утешения, что он «заснул тихо, не испытывая боли» и «погиб за Бога и отечество» [7].

Верховное военное командование уже 11 ноября 1914 г. опубликовало коммюнике, содержащее краткую информацию для населения рейха об итогах кровопролитных боев севернее Ипра. Оно сразу было воспроизведено на первых страницах ведущих газет. В сравнении с действительностью изложение событий было похоже на издевку. В документе не было и речи о бездарном руководстве этим наступлением, о преступной готовности военного командования бездумно жертвовать жизнями тысяч мало обученных новобранцев, циничном отношении к ним как к пушечному мясу [Ibid. S. 49]. Авторы коммюнике стремились отвлечь внимание общественности от военной катастрофы и представить ее успешной операцией. В сообщении превозносился героизм молодых солдат, однако о тысячах погибших в этом бою даже не упоминалось. Документ гласил, что западнее Лангемарка молодые бойцы XXIII резервного корпуса, «бесстрашно демонстрируя презрение к врагу», строем с развевающимися знаменами пошли в атаку на передовые позиции противника, исполняя национальную песню «Германия, Германия превыше всего...». Экспрессивное изложение событий должно было создать впечатление о спонтанном взрыве патриотических чувств у молодых солдат.

Пока коммюнике продвигалось по инстанциям, появилась обновленная версия произошедшего, но и в ней ни слова не было о катастрофических потерях, а сообщалось о студентах и гимназистах, которые якобы прорвали первую линию вражеских позиций и взяли пленными 2 тыс. французских пехотинцев и 6 пулеметов. Следует отметить, что бо́льшая часть населения тыла приняла эту историю на веру и восхищалась героизмом молодых солдат [8]. В частности, Э.-М. Ремарк впоследствии сообщал в интервью писателю Г. Грассу, что осенью 1914 г., когда он был еще школьником, легенда о Лангемарке произвела на него неизгладимое впечатление [9].

При содействии военного руководства официальная пропаганда оперативно формировала миф о Лангемарке. Он основывался исключительно на коммюнике командования и вскоре стал одним из самых популярных мифов в истории Германии первой половины XX в. Творцы мифа из каждого кусочка краткого сообщения искусно выстраивали его составные части. В реальности военные действия проходили близь населенного пункта с неблагозвучным наименованием Биксшоте. Но вместо точного указания места боя в коммюнике предпочтение было сознательно отдано топониму Лангемарк, звучащему якобы более выигрышно как типично прусско-немецкое название, созвучное к тому же слову «Бисмарк» [10].

В сводках подчеркивалось, что бой произошел «заnаднее Лангемарка», чтобы внушить читателю, что немецкие солдаты были охвачены «наступательным духом» и продвинулись вперед. В реальности незначительные успехи были достигнуты на других отрезках ипрского фронта. Вместо указания на конкретные части и батальоны, которые участвовали в сражении, в сообщениях фигурировали лишь «молодые резервисты», «молодые бойцы», хотя среди атакующих были и зрелые мужчины. Такие термины употреблялись и ранее, но с целью подчеркнуть неопытность, «необстрелянность» большинства новоприбывших солдат. Молодежь выдвигалась на первый план намеренно, чтобы пробуждать настроения сопереживания, горестной утраты и гордости за нее. Так, в 224-м пехотном полку из почти 2,9 тыс. человек только 7\% добровольцев имели свидетельство о годичной военной подготовке; треть из них являлись школьниками. Из 1 тыс. военнослужащих 26-го резервного егерского батальона, сформированного в основном из студентов горной академии Фрайбурга, военную подготовку прошли 160 человек [11]. По данным Франкфуртер альгемайне цайтунг, доля молодых солдат в подразделениях не превышала 20\% [12]. Неслучайно, интерпретируя события ипрской битвы, пропагандисты изобрели новую смысловую единицу: «бойня детей» (Kindermord), которая как метафора часто и долго использовалась.

Во всех трактовках мифа о Лангемарке главным его компонентом, а затем и символом стало пение солдат на поле боя. В реальности этого факта сомневались даже современники. Трудно поверить, что прибывшие незадолго до боя неопытные солдаты, обвешанные 30килограммовым вооружением, в предрассветных сумерках, в густом тумане пошли на штурм противника по размокшей из-за затяжных дождей глине свекольного поля с развернутыми знаменами, исполняя патриотическую песню (темп который был медлительный). Но в более поздних исследованиях указывается, что в бою «западнее Лангемарка» «Песнь немцев» использовалась как опознавательный сигнал и как патриотическая песня для поддержания боевого духа, но не при наступлении на вражеские позиции. В частности, Е. Булитта и Г. Булитта пишут, что новобранцы в незнакомой местности и в тумане потеряли ориентировку. Чтобы собраться воедино, они запели песню о Германии, которую знали все и которую многие солдаты исполняли еще до появления на фронте [7]. Другие авторы считают, что в хаосе наступления пением солдаты подавали сигнал о своем присутствии, чтобы избежать обстрела собственной артиллерии, установить связь с соседними батальонами, упуская из вида, что немецкая артиллерия находилась позади солдат на глубине четырех километров. Однако как раз эти невыясненные обстоятельства и давали возможность официальным лицам на свой лад интерпретировать произошедшие события. Пение превратилось в устойчивый компонент мифа о Лангемарке.

Имеются сведения, что опыт этой атаки, несмотря на ее трагизм, нашел последователей. Невзирая на 
свертывание боевых действий по обе стороны фронта, по приказу генерала фон Деймлинга 15 ноября в атаку против французов в сопровождении полкового оркестра с пением были брошены 12 тыс. человек, половина из которых погибла [10]. Лишь 18 ноября немецкие войска получили приказ о прекращении наступления, и вскоре весь Западный фронт перешел к затяжной позиционной войне, создавая из окопов монументальные линии обороны [13]. Героизация солдат, павших под Лангемарком, в течение всей войны выполняла функцию поддержания «боевого духа и воли к противостоянию» у тех, кто был призван на фронт, и у тех, кто должен был вскоре стать новобранцем. В первую годовщину битвы под Лангемарком вышел поток публикаций. Большинство газет вновь поместили на своих страницах коммюнике Верховного военного командования, статьи о героях и их последователях. В статьях вновь живописались образы боя, превозносился героизм «цвета молодежи», но по-прежнему сохранялось молчание по поводу причин и виновниках ее гибели. Вместо слова «смерть» во всех публикациях было поставлено многоточие или оставлено пустое место.

Миф о Лангемарке явился удачной попыткой военного руководства Германии обратить сокрушительное военное поражение в моральную победу, в то время как итог военных действий в северной части Западного фронта протяженностью в 300 километров был удручающим. Командованию не удалось достичь здесь ни одной стратегической цели: ни прорвать фронт союзников по Антанте, ни занять хотя бы один порт. Хотя почти вся Бельгии была оккупирована, бельгийские и английские войска, несмотря на численный перевес немцев, в течение всей войны удерживали небольшую территорию страны, зажатую между Северным морем и p. Изер, которая находилась всего в шести километрах от дислокации германских войск. В борьбе за незначительные территории, приобретенные в результате этого бесславного наступления, немцы потеряли 20 тыс. солдат. Общие их потери в первой фламандской битве составили 130 тыс. убитыми и ранеными [6].

Беспощадная расправа, которую пережили молодые добровольцы, ужасающие разрушения окрестностей, беспорядок в частях кардинально изменили их настроение. В работе Ф. Виткофа «Военные письма немецких студентов» (1916), которая формировала образ «поколения Лангемарка», показан переход новобранцев от былого энтузиазма к отчаянию. Один из них 28 октября 1914 г. писал из Диксмюде: «С какой радостью и восторгом я отправился воевать, война казалась мне наивысшим поводом позволить себе жизненный порыв и испытать живой восторг. С каким разочарованием сижу я здесь - ужас в сердце» [14. S. 47].

Немецкий ученый Б. Хюппауф, изучавший феномен Лангемарка, отмечает, что в годы Первой мировой войны в Германии было создано два мифа, которые сосуществовали, противостояли и усиливали друг друга. Первый - миф о Лангемарке «вдувал жизнь» в тра- дицию прошлого с его идеалами рыцарства героизма и жертвенности и прославлял их. Этот миф создавался консерваторами и националистами с целью внушить, что «молодежь» Лангемарка доказала «возрождение героического человека», омоложение духа нации и право на представительство ментальности всех буржуазных групп [14. S. 49]. Однако повторяемые как заклинание лозунги: «Самая большая победа - умереть за отечество», «Отдельный человек - ничто, народ - все», в первую очередь были обращены к молодежи [15. C.47]. Миф стал инструментом воспитания целого «поколения Лангемарка». Ему внушали, что от его борьбы и даже смерти зависит спасение германского народа, нации, государства. Самопожертвование «героев Лангемарка» провозглашалось эталоном, равняться на который должны были не только солдаты, но и немцы тылового общества. Таким образом, через молодежь эти призывы транслировались всем немцам.

Создание второй редакции мифа началось в 1916 г., когда военное командование Германии осмысливало опыт «великой войны», особенно сражения под Верденом, которое унесло жизни почти 1 млн человек. Военное руководство провозгласило, что идет «битва материалов», от объемов производства которых зависит исход войны. Солдат в этом контексте был приравнен к боеприпасам, вооружениям и рассматривался лишь как одна из разновидностей «материалов». Командование поставило задача создать «иконографию солдата нового типа». По оценке Б. Хюппауфа, этот миф был отмечен «агрессивностью, футуристически-нигилистическими чертами». Вместо героя Лангемарка - эмоционального, спонтанного идеалиста, идущего на смерть, предстает фигура бойца «новой конструкции» - вымуштрованного, хладнокровного и технически хорошо вооруженного, который без оглядки на мораль и политические последствия претворяет уроки фронта в жизнь [14. S. 43-44]. Воин нового типа должен был стать аналогом «боевой машины» (Kampfmaschine). Его визуальными символами явились автоматический пулемет, газовая маска и стальной шлем, которые олицетворяли современную высокотехничную, функциональную войну. Боец «новой конструкции» потеснил образ юного солдата-идеалиста из легенды о Лангемарке. Но ссылки на него все же сохранились, только пропаганда перенесла акцент в трактовке его образа на такие качества, как воля к победе, безоговорочная готовность служить кайзеру, народу, фатерланду, демонстративное презрение к смерти [16. S. 108].

Миф о Лангемарке выстраивался в целях решения задач, стоящих перед германскими националистами, и вылился в кампанию героизации и эстетизации мученической смерти погибших. Немецкий исследователь А. Вайнрих пишет, что с точки зрения культуры памяти в мифе о Лангемарке акцентом сакрального смысла был сделан чистый героизм, в котором не было места трезвому расчету и сопоставлению оперативной цели и возможных потерь. В пространственно-временном плане 
«Лангемарк» не стал «поэтической банальностью, порожденной первой фламандской битвой октября / ноября 1914 г.». Он сотворил неразрывную триаду: молодежь, жертвенность и смерть, а героическую смерть молодых немцев возвел в ранг обязательного кода поведения молодежи на всех фронтах и на всю войну. Милитаристы, создавая культ молодежи, безжалостно навязывали ей культ смерти. Молодых людей убеждали, что «самая большая победа - это умереть за отечество». Смерть или готовность к смерти должны были стать самоцелью. Творцы мифа стремились внедрить в молодежную культуру установку на героизм и самопожертвование. Логика действий героев Лангемарка - бросится навстречу верной смерти, исполнить свой долг и добиться моральной побе$\partial b l$ - навязывалась как эталон [17].

Большой вклад в эту кампанию внесли деятели культуры Германии. В широко известной песне «Прощание солдата» (1916 г.) на слова поэта Г. Лерша звучало «Пусть живет Германия, даже если мы умрем». Стихотворец В. Флекс писал, что «война - это алтарь, на котором из германской крови Бог готовит свое вино»; «...под мечами и знаменами гаснет наша улыбка». Герой Первой мировой войны и писатель Эрнст Юнгер и в 70 лет помнил текст «Фландрской пляски мертвых»: «Фландрия в беде, Фландрия в огне, смерть скачет по ней на черном коне» [18].

Значительное число солдат оказалось восприимчиво к идеям, составляющим ядро мифа о Лангемарке. Примечательно, что даже в конце войны многие из них оставались привержены им. Хотя большинство их со временем осознало бессмысленность и жестокость империалистической войны, но они считали необходимым выполнять свой долг, ставили его выше страданий и страхов. Так Карл Шенкель в письме от 20 апреля 1917 г. сообщает родным о локально успешном противостоянии англичанам в районе Арраса: «...вы в тылу ощущаете благодарность, ...но она предназначена Богу, а не нам - мы выполняем наш долг ....И если однажды от нас потребуется последняя жертва, мы... отбросим ненужные жалобы и надломы, ибо в такой момент война как раз является испытанием нашей веры. Да, печально, но по-другому мы не сможем поступить... нам под силу следующее: для нас самих - из боли создать благодать, для других - стать им образцом для подражания» [19].

Миф о Лангемарке был сфабрикован по инициативе и усилиями милитаристских сил, уловивших ментальный настрой так называемой образованной буржуазии, прежде всего ее более молодых групп, адептов «нового национализма». Последние связывали с войной надежды как на повышение значимости Германии в мире, на территориальные приобретения, так и на обновление общества, проникнутого стагнацией, косностью, традиционализмом. Б. Хюппауф, исследуя истоки популярности мифа о Лангемарке, указывает, что на сознание и подсознание националистически настроенных немцев действовали красочные архетипы этого мифа: рыцарское поведение, чувство товарищества (Катеradschaft), верность долгу, приоритет нации и Германии над индивидуализмом. В годы военных потрясений и изломов убеждения и культурные ориентации многих людей подвергались эрозии и трансформации, а их социальная идентичность на фронте и в тылу размывалась, оказываясь на грани утраты. Миф о Лангемарке способствовал их стабилизации, которую они старались обрести, обращаясь к образцам прошлого. Им казалось, что «сияющий свет, который исходил от этого мифа, вновь давал им возможность устоять и утвердиться, несмотря на заслуживающую проклятия действительность, в которой самым тяжелым были последствия фронтового опыта и поражение 1918 г.» [14. S. 47].

Призывы помнить о героях Лангемарка и подражать им на протяжении всей войны содержались в речах военных и государственных деятелей, священников, руководителей молодежных организаций, в печати, в школьных и вузовских учебниках, даже в детских журналах. Среди лавины патетических публикаций, появившихся в первую годовщину Лангемарка, было немало статей, в которых, наконец, заговорили о смерти участников боев севернее Ипра. Но акцент в них был сделан не на осуждении виновников, а на прославлении самопожертвования молодежи [10]. Авторы публикаций требовали увековечить память героев: внести день битвы в реестр памятных дат нации, воздвигать мемориалы в их честь, проводить дни поминовения в школах и вузах для сохранения памяти о них.

Воздаяние почестей погибшим во время войны, а затем и в годы Веймарской республики превратилось в «разновидность поминальной службы» по ним. Неслучайно уже в годы Веймарской республики день Лангемарка отмечался в стиле, присущем церковной службе. Выполнение ритуала, особенно ветеранами войны, воспринималось как гарантия того, что высокие моральные качества и верность долгу, проявленные героями, будут и впредь передаваться от поколения поколению. Упомянутый поэт В. Флекс пророчил, что «слава воинов породит таких же внуков» [16. S. 110]. Участие в чествовании павших при Лангемарке помогало участникам войны справиться с собственным страхом по поводу того, что и они «могут выпасть из истории», т.е. будут забыты. Во время войны пропаганда твердила, что в кровопролитных битвах решается вопрос «быть или не быть» Германии, и эта дилемма страшила не только перспективой национального позора в случае поражения, но и возможностью утраты «места своего бытия в мире истории». Гарантией от такого исхода являлась верность памяти жертв Лангемарка. Поклонение им стало знаком борьбы с угрозами будущего [14. S. 44]. День Лангемарка уже в годы войны вошел в реестр военных национальных памятных дат, его отмечали наряду с датами битвы при Танненберге, Лейпцигской битвы, битвы под Седаном.

Миф о Лангемарке содействовал возникновению в Германии целого культурного пласта. В эпоху Веймара 
поэты, писатели, композиторы, публицисты посвящали героям свои стихи, драмы, песни, эссе. Памятные доски, барельефы и витражи напоминали о них в церквях. К теме Лангемарка обращались такие известные художники, как Отто Дикс и Кэте Кольвец, которая потеряла 17-летнего сына-добровольца в Бельгии и возвела на месте его гибели памятник молодежи, обманутой и безжалостно принесенной в жертву.

После проигранной войны потребность в культе героев, сложивших головы во благо рейха, еще более возросла, что повлекло за собой дальнейшую институционализацию мифа о Лангемарке. 10 ноября 1919 г. военнослужащие XXII резервного корпуса впервые провели в Берлине день памяти битвы. Он проходил в помпезном соборе, посвященном императору Вильгельму II. Многолюдные чествования состоялись в гарнизонной церкви Потсдама, известного своими милитаристскими традициями. Блок правых сил Веймарской республики, а затем нацисты, используя популярность мистификации о Лангемарке, представляли его антитезой, оппозицией Ноябрьской революции, развязанной социалистами, демократами и евреями, которая нанесла Германии «удар в спину кинжалом». Лангемарк толковался и как противовес Веймару, «соглашательской» политике его лидеров, подписавших грабительский Версальский договор. По утверждению националистов, правительство республики предало память павших героев.

Особую активность в сохранении памяти о Лангемарке проявили союзы студентов и молодежи и объединения участников войны. В 1921 г. они создали Комитет Лангемарка высшей школы и армии, который руководил устройством «дней Лангемарка» в вузах, вооруженных силах, школах, молодежных союзах. С 1928 г. эти торжества стали ежегодными и проводились в вузах по всей Германии. В 1929 г. в Берлине на организованное при участии студенческих комитетов имперское чествование Лангемарка у Дворца спорта собралось 150 тыс. человек [20]. Особо пышные церемонии были организованы в юбилейные годы: 1919, 1924, 1929 и в 1932 гг. На открытие памятника павших в горах Рен в десятую годовщину сражения прибыли 2 тыс. представителей молодежных союзов. В годы Веймара в проведении торжеств Лангемарка участвовали высшие офицеры, лидеры и члены консервативных, ветеранских и националистических союзов. В конце 1920-х гг. помощь в их организации неофициально оказывали земельные правительства. Повышению престижа акций памяти Лангемарка содействовало присутствие на них принцев Пруссии и Баварии. В 1929 г. из студенческих групп, которые вышли из подчинения боевому союзу фронтовиков «Стальной шлем», и членов союза фехтовальщиков «Ваффенринг» был создан Круг студентов Лангемарка с целью демонстрации верности памяти молодыx героев.

В годы республики отдельные группы немецкого общества стремились придать чествованию павших антивоенный смысл, сделать его символом примирения сторон, но эта интерпретация не стала доминирующей.
С 1928 г. немецкое студенчество взяло «Лангемарк» под особую опеку. Немецкий Союз студентов создал «Общество пожертвований на Лангемарк» для финансирования работ по созданию «Немецкого солдатского кладбища № 123» в бельгийской Фландрии неподалеку от места битвы. К 1932 г. оно было преобразовано в мемориал. Его территория была окаймлена дубами и окружена валом и рвом. Вход на кладбище был оформлен воротами из красного песчаника. В одном из мемориальных помещений были размещены дубовые доски с выявленными именами павших. Во дворе располагалась большая братская могила, где были похоронены останки около 25 тыс. немецких солдат, большинство имен которых были неизвестны. Со временем были выявлены фамилии 17 тыс. погребенных. Их имена отлили на бронзовых досках, закрепленных на массивных каменных глыбах, обрамляющих братскую могилу с трех сторон. Позднее на это мемориальное кладбище были перенесены останки немецких солдат из других мест Фландрии, и общая численность захоронений достигла 44 тыс. На заднем плане располагалась скульптурная группа из бронзы «Скорбящие солдаты», созданная скульптором Э. Кригером. В северной части вдоль частично сохранившейся линии фронта располагались три отреставрированных блиндажа и 52 каменных саркофага с надписями воинских частей и студенческих союзов, которые участвовали в сборе пожертвований на восстановление кладбища [10]. В эпоху Веймара во многих населенных пунктах Германии появились памятники и мемориалы преимущественно в псевдоантичном стиле. Многие из них были установлены церковными общинами или по частной инициативе граждан [18].

Нацисты подхватили миф о Лангемарке и превратили его в инструмент своей политики в 1928 г. До этого Гитлер отделывался приветственными репликами в адрес его героев. Он считал, что миф носит элитарный характер, поскольку объектом прославления были студенты (как правило, принадлежащие буржуазным слоям). Фюрер отмечал, что у них было много энтузиазма, но не хватало решимости [10]. Обострившаяся в конце 1920-х гг. внутриполитическая борьба и погоня за электоратом побудили нацистов акцентировать участие в битве молодых рабочих, ремесленников, торговцев, крестьян и студентов, что должно было подчеркнуть «общенародный» состав павших солдат, доказательство наличия в Германии «народного сообщества». Однако со временем, как и консерваторы, нацисты стали утверждать, что Лангемарк может стать «символом программы омоложения немецкой нации». Они заявляли, что образованная молодежь с ее «страстной тоской по “смыслу” истории и поисками “метафизического пристанища" может пойти по следу Лангемарка и найти пристанище в нацистской партии» [14. S. 49].

В годы Третьего рейха «Лангемарк» не только был принят, но расширен и преобразован. Стилизованный миф давал нацистам возможность прославлять войну как таковую, воспитывать молодежь в духе расизма, реванша и агрессии. Нацистская пропаганда твердила, что социа- 
листы и демократы предали забвению подвиг героев: демократы радовались перемирию 11 ноября 1918 г., а социалисты привели Германию 9 ноября 1918 г. к революции и предали дело героев Лангемарка. Осенью 1933 г. во многих немецких городах синхронно состоялась премьера героической драмы боннского писателя Г. Церкаулена «Молодежь Лангемарка», а затем «Отчет о штурме Лангемарка» Э. Кана и М. Гейслера-Монато. С согласия Гитлера Союз ветеранов XXVI резервного батальона, участвовавшего в Ипрской битве, учредил в 1933 г. «Крест за Лангемарк» в качестве неофициальной почетной награды [18]. Нацисты положили начало переименованию улиц и площадей в честь Лангемарка.

В 1934 г. проведение акций чествования Лангемарка и пожертвований на него было передано под контроль официальной молодежной организации НСДАП «Гитлерюгенд», которая оттеснила на второй план студенческие организации и даже рейхсвер. Нацисты переименовали общество «Пожертвований немецкого студенчества на Лангемарк» на «Пожертвования немецкой молодежи».

В этот же год была учреждена и трехсеместровая программа «Лангемаркского обучения», которая действовала почти до конца Второй мировой войны. Ее выполняли многие ведущие университеты рейха. Этот проект предназначался для «одаренных молодых мужчин... из всех слоев, сословий и профессий» 17-24 лет, не имевших аттестата о полной школе. В 1937 г. была установлена ежегодная квота приема на программу 1 тыс. человек. Малоимущие имели право на бесплатное обучение. На деле попасть на «Лангемаркское обучение» было непросто, так как возможность свободного поступления и выбора курсов исключалась. Претендовать на участие в программе могли только члены подразделений НДСАП, в первую очередь ее молодежных организаций (в годы войны и вермахта), или молодые люди, получившие их рекомендацию, а также лица, отслужившие в вермахте или выполнившие трудовую повинность. Отбор производился после проверки в специальных лагерях на соответствие критериям «расовой чистоты», приверженности идеологии националсоциализма, а также состояния «физического здоровья и наличия функциональных способностей» [21]. Целями «Лангемаркского обучения» была подготовка кадров, преданных режиму, и демонстрация дееспособности «народного сообщества», обеспечивающего якобы широкую доступность высшего образования. Лангемарку были посвящены спортивные состязания молодежи, в которых видное место занимала военная подготовка.

В эпоху нацизма Лангемарку было отведено почетное место и в историческом здании Новая вахта. Она была возведена еще в 1818 г. в центре Берлина как пост караула короля Пруссии. В годы Первой мировой войны в ней был размещен центральный военный телеграф. В 1931 г. архитектор Г. Тессенов преобразовал это сооружение в мемориал. Новая вахта являлась местом почитания не только героев Лангемарка, но и немцев, павших в эпоху наполеоновских войн за освобождение Германии, а также «бойцов движения»: нацистов, которые погибли в период «пивного путча» 1923 г. и в ходе столкновений с их политическими противниками.

«Лангемарк» был интегрирован и в Имперское спортивное поле - монументальный стадион, построенный для проведения Олимпийских игр в Германии в 1936 г. Сооружения стадиона занимали 132 га, на нем могли разместится 100 тыс. человек. В боковой части комплекса архитектором В. Мархом была возведена величественная 80-метровая кампанила - колокольня с олимпийским колоколом, посвященная Адольфу Гитлеру [22]. В цокольном этаже кампанилы был создан Зал Лангемарка, предназначенный для чествования бойцов, погибших в ипрской битве. Павильон был оформлен в стиле античного храма, декорирован знаменами полков и табличками с именами павших. Залу было предназначено стать национальным символом культа жертвы. В деревянном алтаре находился ларец с землей с кладбища № 123 во Фландрии, которую привез организатор Олимпийских игр Карл Дьем, ветеран Первой мировой войны. Архитектор вписал мемориал в сооружение стадиона ради реализации идеи, что «спорт должен закалять германскую молодежь для войны и готовить к жертвенной смерти» [23]. Демонстрацией «слияния культа тела и спорта с культом жертвы и солдатского мужества» явился перенос официальных чествований героев Лангемарка на Майское поле стадиона, созданное для массовых манифестаций. Но после того как летом 1940 г. нацисты оккупировали Францию и Бельгию и вермахт и верхушка нацистов праздновали эти событие как «подлинное окончание Первой мировой войны», очередное и последующие чествования павших героев были перенесены на кладбища Лангемарка и Вердена. Там организаторы торжественно провозгласили: «И все же вы победили!», и в этом с ними было согласно большинство немцев. Роль Зала Лангемарка резко снизилась. В конце Второй мировой войны он был разрушен, его «святыни» бесследно утрачены.

В годы Второй мировой войны, когда требовалось постоянно наращивать мощь армии, гитлеровцам пришлось отступить от принципов расовой чистоты и пойти на создание дивизий СС из жителей оккупированных стран. В октябре 1944 г. из молодых фламандских и немецких добровольцев была сформирована 27-я гренадерская дивизия CC «Langemarck» [24].

Катастрофическое поражение нацистов во Второй мировой войне и разоблачение его преступлений постепенно меняли и отношение немецкого общества к войне. В эпоху ФРГ для «демилитаризации сознания» легенду, приукрашенную до неправдоподобия, со временем разобрали по пунктам, и теперь она включена в немецкую историю лишь как миф о Лангемарке [25]. Он, как и другие националистически-милитаристские мифы, потерял свое значение, хотя публичные дискуссии по поводу снесения мемориалов и памятников, переименования улиц и пр. развернулись не сразу. 
Постепенно преобразовывались и «места памяти», связанные с этим топосом. Вплоть до объединения Германии совершались военные ритуалы у Новой вахты, но они происходили редко и утратили свой прежний подтекст. В 1960-1962 гг. Марх восстановил колокольню и Зал Лангемарка, но удалил «трибуну Гитлера» перед ним. Полностью павильон был реконструирован и отреставрирован к чемпионату мира по футболу в 2006 г. Немецкий исторический музей 4 мая 2006 г. организовал там выставку на тему спорта, истории и политики, которая поставила целью создать «противоядие против мифа о Лангемарке». Тем не менее выставка получила неоднозначные оценки.

В 1957, 2006 и 2015 гг. реконструировалось и обновлялось военное кладбище во Фландрии. В 2006 г. на его северной стороне соорудили туннельный павильон, в котором непрерывно демонстрируют кинокадры войны, географический обзор мест сражений и расположений бывших солдатских захоронений в регионе, а также историю солдатского кладбища Лангемарк. В настоящее время его курирует Национальный союз по уходу за военными захоронениями. Кладбище посе- щают ежегодно около 100 тыс. человек. Оно рассматривается как «место памяти» нации [25]. Многие памятники, посвященные Лангемарку, уцелели, потому что не слишком бросаются в глаза и их знают лишь немногочисленные ценители и специалисты.

Ныне более чем в 20 городах ФРГ сохранились улицы и площади, носящие имя Лангемарка. Но многим современным школьникам это название уже ничего или почти ничего не говорит. Старшее поколение осведомлено лучше, и Лангемарк олицетворяют в их сознании не только две тысячи «молодых резервистов», погибших в бессмысленной атаке, но и всех студентов и молодых людей, которые действительно могли стать «цветом нации», но, одурманенные националистической пропагандой, пали на фронтах этой кровавой войны. По свидетельству профессора теологии Т. Шредера, на фронты Первой мировой войны было призвано 90\% студентов Германии, 20\% из них погибли. Ученый пишет о «преданном кураже» молодых солдат, чей энтузиазм был использован для реализации навязчивой идеи мирового господства правящей верхушки Германии [26].

\section{ЛИТЕРАТУРА}

1. URL: https://www.dhm.de/lemo/jahreschronik/1914

2. Flemming Th., Ulrich B. Heimatfront. München : Bucher Verlag, 2014.

3. URL: https://www.volksbund.de/fileadmin/redaktion/BereichInfo/BereichPublikationen/Friedenserziehung/Handreichungen/0082_Kindersoldaten.pdf

4. URL: http://первая-мировая.pф/article/item/39

5. URL: http://germans-medal.com/shop/znaki-organizacij/znak-v-chest-20-ti-letiya-bitvy-za-langemark-1914-1934/

6. URL: https://topwar.ru/65784-bitva-za-flandriyu.html

7. Bulitta E., Bulitta H. Um die Jugend betrogen (Hrsg.). Kindersoldaten. URL: http://docplayer.org/128142-Kindersoldaten-paedagogischehandreichung-von-erich-und-hildegard-bulitta.html

8. URL: http://deredactie.be/cm/vrtnieuws.deutsch/I.WK/1.2144738

9. URL: http://webcache.googleusercontent.com/search?q=cache:LKvt4eisszYJ:www.libed.ru/knigi-nauka/1078513-1-annotation-gyunter-grass-chelovek-sumevshiy-naryadu-odnim-lish-sartrom-voplotit-svoem-tvorchestve-ves-vek-vse.php $+\& \mathrm{~cd}=8 \& \mathrm{hl}=\mathrm{ru} \& \mathrm{ct}=\mathrm{clnk} \& \mathrm{gl}=\mathrm{ru}$

10. URL: https://p-w-w.org/index.php?topic $=16242.0$

11. URL: https://de.wikipedia.org/wiki/Erste_Flandernschlacht

12. URL: http://www.faz.net/aktuell/politik/der-erste-weltkrieg/der-mythos-von-langemarck-13256715/eine-zerstoerte-strasse-in-13256701; hhttp:// www.faz.net/aktuell/politik/der-erste-weltkrieg/der-mythos-von-langemarck-13256715/eine-zerstoerte-strasse-in-13256701.h

13. URL: http://osutivremeni.ru/flandrskoe-srazhenie-pervaja-bitva-pri-ipre/

14. Hüppauf B. Schlachtenmythen und die Konstruktion des «Neuen Menschen»//Keiner fühlt sich hier mehr als Mensch. Erlebnis u. Wirkung des Ersten Weltkrieges. Hrsg. v. Hirschfeld G, Krummeich G. // Verbindung mit Renz I. Essen : Kartext Verlag, 1993.

15. Hamann Br. Der Erste Weltkrieg. Wahrheit und Lüge in Bildern und Texten. München : Piper, 2014.

16. Reulecke J. «Ich möchte einer werden so wie die...». Männerverbände im 20. Jahrhundert. Fr. a M. : Campus-verlag, 2001.

17. Weinrich A. Kult der Jugend - Kult des Opfers: der Langemarck-Mythos in der Zwischenkriegszeit // HistoricalSocial Research. 2009. Vol. 34 , № 4. P. 319-330. URL: https://www.ssoar.info/ssoar/bitstream/handle/document/28775/ssoar-hsr-2009-no_4_no_130-weinrich-kult_der_jugend_kult.pdf?sequence=1DOI:vjhfkmyjq

18. URL: http://webcache.googleusercontent.com/search?q=cache:LKvt4eisszYJ:www.libed.ru/knigi-nauka/1078513-1-annotation-gyunter-grass-chelovek-sumevshiy-naryadu-odnim-lish-sartrom-voplotit-svoem-tvorchestve-ves-vek-vse.php $+\& \mathrm{~cd}=8 \& \mathrm{hl}=\mathrm{ru} \& \mathrm{ct}=\mathrm{clnk} \& \mathrm{gl}=\mathrm{ru}$

19. URL: http://www.lexikon-erster-weltkrieg.de/Feldpost:_Karl_Schenkel

20. URL: https://starcom68.livejournal.com/1558061.html

21. URL: https://de.wikipedia.org/wiki/Langemarck-Studium

22. URL: http://www.deutschlandfunkkultur.de/mythos-langemarck-entzaubert.1001.de.html?dram:article id=156033

23. URL: https://www.focus.de/wissen/mensch/geschichte/erster-weltkrieg/vergessene-mythen-die-schlacht-bei-langemarck-so-schlau-nutzte-die-nazipropaganda-das-gemetzel-von-1914_id_6054185.html

24. URL: http://historicaldis.ru/blog/43240785853/SCHUTZSTAFFEL-(CHto-takoe-SS)

25. URL: https://vk.com/wall-8300406_43354?offset=last\&f=replies

26. Schröder T. Verratene Courage - Studenten im Ersten Weltkrieg. URL: http://www.uni-stuttgart.de/esg/zettelkasten/Schroeder\%202015\%20$\% 20$ Verratene $\% 20$ Courage $\% 20-\% 20$ Studenten $\% 20 \mathrm{im} \% 20$ Ersten $\% 20$ Weltkrieg.pdf

\section{Suprygina Galina G. National Research Tomsk State University (Tomsk, Russian Federation). E-mail: askis@ngs.ru}

THE TRANSFORMATION OF «THE MYTH OF THE LANGEMARKE» IN THE GERMAN HISTORY OF THE TWENTIETH CENTURY

Keywords: the myth of Langemark; young fighters of Germany in World War I; the myth of Langemark in the year of national socialism; Langemark as place of memory.

The article focuses on the sentiments of excitement among wide groups of German society, especially youth groups, at the beginning of the war. It was due to these sentiments that most of the young and poorly trained soldiers who were ordered to advance on the wellfortified positions of the British army in the Battle of Langemark in Flanders perished. Avoiding their responsibility for the losses in killed and wounded the Supreme military Command of Germany interpreted the event as "moral victory of the youth". The militarists 
glorified heroism and readiness to self-sacrifice of the perished soldiers and imposed these ideas on the German youth as a code of conduct at the front and in the rear.

This myth served the basis for glorification of the heroes of Langemark during the time of the Weimar Republic. Remembrance pray was to save the victims of the bloody war from oblivion. The day of the Battle was celebrated as one the national holidays; there appeared memorials dedicated to war heroes and the tradition of remembrance was observed at secondary and higher schools as well as in the army.

During the period of Third Reich the ideas of the myth were used by the Nazis to glorify the war, educate young generation in the spirit of racism and aggression and recruit them into their party. They introduced the practice of renaming streets and squares in honor of Langemark and passed on the right of honoring heroes to their youth organization Hitlerjugend. A special Langemarks teaching program aimed at training at higher schools young people from lower classes as devoted and loyal cadres to the regime and as well as glorification the possibilities of the "people's community" created by Nazis was carried out through the war.

The "Hall of Langemark" built in the chapel on the Imperial Stadium errected for the Olympic Games in Germany of 1936 served as sanctuary. Annual sport competitions in honor of Langemark were aimed at improving military training of the young.

The myth of Langemark was debunked during the process of "demilitarizaition of mind" in the Federal Republic of Germany. Most of the monuments and memorials have survived and are taken by German population as symbols reminding of young people who fell as victims of German nationalist and militarist's claims to word domination during the two wars.

The myth of Langemark proved to be the most popular among such legends of the XX century. The myth makers created a triad: of cult victims, death cult and the cult of youth. The myth was subjected to transformations for the sake of mobilizing the younger generation to meet the challenges set by right-wing forces of Germany.

\section{REFERENCES}

1. Lebendiges Museum Online. (n.d.) Chronik 1914 [Chronicle 1914]. [Online] Available from: https://www.dhm.de/lemo/jahreschronik/1914.

2. Flemming, Th. \& Ulrich, B. (2014) Heimatfront [Homefront]. München: Bucher Verlag.

3. National Association of Bavaria Volksbund Deutsche Kriegsgräberfürsorge. (n.d.) Um die Jugend betrogen - Kindersoldaten [Cheated on the youth child soldiers]. [Online] Available from: https://www.volksbund.de/fileadmin/redaktion/BereichInfo/BereichPublikationen/Friedenserziehung/Handreichungen/0082_Kindersoldaten.pdf.

4. Zaionchkovskiy, A.M. (n.d.) Srazheniye vo Flandrii (oktyabr' - noyabr' 1914 g.) [The Battle of Flanders (October - November 1914)]. [Online] Available from: http://первая-мировая.pф/article/item/39.

5. German-medal.com. (n.d.) Znaki organizatsii [Signs of the organization]. [Online] Available from: http://germans-medal.com/shop/znakiorganizacij/znak-v-chest-20-ti-letiya-bitvy-za-langemark-1914-1934/.

6. Samsonov, A. (n.d.) Bitva za Flandriyu [The Battle of Flanders]. [Online] Available from: https://topwar.ru/65784-bitva-za-flandriyu.html.

7. Bulitta, E. \& Bulitta, H. (eds) (n.d.) Um die Jugend betrogen. Kindersoldaten [Cheated on the youth. Child soldiers]. [Online] Available from: http://docplayer.org/128142-Kindersoldaten-paedagogische-handreichung-von-erich-und-hildegard-bulitta.html.

8. Kockartz, A. (2014) Propagandalüge oder Der Mythos von Langemarck [Propaganda lie or The myth of Langemarck]. [Online] Available from: http://deredactie.be/cm/vrtnieuws.deutsch/I.WK/1.2144738.

9. Grass, G. (n.d.) Moe stoletie [My century]. [Online] Available from: http://webcache.googleusercontent.com/se-arch?q=cache:LKvt4eisszYJ: www.libed.ru/knigi-nauka/1078513-1-annotation-gyunter-grass-chelovek-sumevshiy-naryadu-odnim-lish-sartrom-voplotit-svoem-tvorchestve-vesvek-vse.php $+\& \mathrm{~cd}=8 \& \mathrm{hl}=\mathrm{ru} \& \mathrm{ct}=\mathrm{clnk} \& \mathrm{gl}=\mathrm{ru}$.

10. Globalnyy khutorok. (n.d.) Mif o Langemarke [The Myth of Langemark]. [Online] Available from: https://p-w-w.org/index.php?topic=16242.0.

11. De.wikipedia.org. (n.d.) Erste Flandernschlacht [The First Battle of Flanders]. [Online] Available from:

https://de.wikipedia.org/wiki/Erste_Flandernschlacht.

12. Wande, A. (2014) Langemarck, der verschleierte Irrsinn [Langemarck, the veiled insanity]. [Online] Available from: http://www.faz.net/aktuell/politik/der-erste-weltkrieg/der-mythos-von-langemarck-13256715/eine-zerstoerte-strasse-in-13256701.

13. Liveinternet.ru. (2013) Flandrskoye srazheniye - pervaya bitva pri Ipre [The Battle of Flanders - the first battle of the Ipra]. [Online] Available from: http://osutivremeni.ru/flandrskoe-srazhenie-pervaja-bitva-pri-ipre/

14. Hüppauf, B. (1993) Schlachtenmythen und die Konstruktion des Neuen Menschen [The myth of the Battle and the construction of the New Man]. In: Hirschfeld, G. \& Krummeich, G. (eds) Keiner fühlt sich hier mehr als Mensch. Erlebnis u. Wirkung des Ersten Weltkrieges [No one here feels more than human. Experience and effect of the First World War]. Essen: Kartext Verlag.

15. Hamann, Br. (2014) Der Erste Weltkrieg. Wahrheit und Lüge in Bildern und Texten [he First World War. Truth and lies in pictures and texts]. Munich: Piper.

16. Reulecke, J. (2001) Ich möchte einer werden so wie die . . Männerverbände im 20. Jahrhundert [I want to be one of those .. . Men's associations in the 20th century]. Frankfurt am Main: Campus-verlag.

17. Weinrich, A. (2009) Kult der Jugend - Kult des Opfers: der Langemarck-Mythos in der Zwischenkriegszeit [Cult of Youth - cult of the victim: the Langemarck myth in the interwar period]. Historical Social Research. 34 (4). pp. 319-330. [Online] Available from: https:/www.ssoar.info/ssoar/bitstream/handle/document/28775/ssoar-hsr-2009-no_4_no_130-weinrich-kult_der_jugend__kult.pdf? sequence=1DOI:vjhfkmyjq

18. Grass, G. (n.d.) Moe stoletie [My century]. [Online] Available from: http://webcache.googleusercontent.com/search?q= cache:LKvt4eisszYJ:www.libed.ru/knigi-nauka/1078513-1-annotation-gyunter-grass-chelovek-sumevshiy-naryadu-odnim-lish-sartrom-voplotitsvoem-tvorchestve-ves-vek-vse.php $+\& \mathrm{~cd}=8 \& \mathrm{hl}=\mathrm{ru} \& \mathrm{ct}=\mathrm{clnk} \& \mathrm{gl}=\mathrm{ru}$.

19. Schenkel, K. (2017) Feldpost: Karl Schenkel [Field Post: Karl Schenkel]. [Online] Available from: http://www.lexikon-ersterweltkrieg.de/Feldpost:_Karl_Schenkel.

20. Starcom68. (2014) Pamyatniki nemetskim soldatam [Monuments to the German soldiers]. [Online] Available from: https://starcom68.livejournal.com/1558061.html.

21. De.wikipedia.org. (n.d.) Langemarck-Studium [Langemarck Study]. [Online] Available from: https://de.wikipedia.org/wiki/Langemarck-Studium.

22. Stock, A. (2006) Mythos Langemarck entzaubert [The Langemarck Myth Disenchanted]. [Online] Available from: http://www.deutschlandfunkkultur.de/mythos-langemarck-entzaubert.1001.de.html?dram:article_id=156033.

23. Wiederschein, H. (2016) Wie die Nazi-Propaganda ein Gemetzel aus dem Ersten Weltkrieg für sich nutzte [How the Nazi propaganda used a carnage from the First World War for itself]. [Online] Available from: https://www.focus.de/wissen/mensch/geschichte/erster-weltkrieg/vergessene-mythendie-schlacht-bei-langemarck-so-schlau-nutzte-die-nazi-propaganda-das-gemetzel-von-1914 id 6054185.html.

24. Vorobiev, S. (2014) Schutzstaffeln (Chto Takoye SS) [Schutzstaffeln (What is SS)]. [Online] Available from: http://historicaldis.ru/ blog/43240785853/SCHUTZSTAFFEL-(CHto-takoe-SS).

25. Vkontakte. (n.d.) [Online] Available from: https://vk.com/wall-8300406 43354?offset=last\&f=replies.

26. Schröder, T. (2015) Verratene Courage - Studenten im Ersten Weltkrieg [Betrayed courage - students in the First World War]. [Online] Available from: http://www.uni-stuttgart.de/esg/zettelkasten/Schroeder $\% 202015 \% 20-\% 20$ Verratene $\% 20$ Courage $\% 20-\% 20$ Studenten $\% 20 \mathrm{im} \% 20$ Ersten $\%$ 20Weltkrieg.pdf. 